Szymon Trusewicz

Wydział Filologiczny

Uniwersytet w Białymstoku

e-mail: sztr@o2.pl

\title{
Literacka mapa Eugeniusza Tkaczyszyna-Dyckiego
}

Miejsca, o których czytamy w poezji Eugeniusza Tkaczyszyna-Dyckiego, z łatwością można odnaleźć na mapie Polski. Liczne toponimy obecne w tej twórczości pozwalają na czytanie wierszy Tkaczyszyna-Dyckiego w kontekście geopoetyki. W niniejszym artykule proponuję interpretację wierszy autora Liber mortuorum za pomocą popularnego od niedawna narzędzia mapy literackiej.

Interdyscyplinarny dialog, który nawiązały ze sobą w ostatnich kilkudziesięciu latach geografia i literatura, pozwala na przenikanie się obu dyscyplin i daje szanse na odświeżenie bliskich zarówno geografom, jak i literaturoznawcom pojęć. Dobrym przykładem może być mapa, która na polu literaturoznawczym przestaje być rozumiana jedynie jako temat, motyw czy metafora, lecz funkcjonuje również jako narzędzie interpretacyjne pomocne $\mathrm{w}$ odczytywaniu przestrzeni kreowanej w dziele literackim, a także jako metafora epistemologiczna, za pomocą której można pisać o kulturowym i społecznym uwarunkowaniu literatury. Popularność mapy w dyskursie humanistycznym jest konsekwencją zwrotu topograficznego, o którym pisze m.in. Elżbieta Rybicka ${ }^{1}$. „Zwrot” w humanistyce oznacza przesunięcie kategorii z poziomu opisu na poziom operacyjności. Przykładem takiej zmiany znaczeniowej w literaturoznawstwie jest zarówno mapa, jak i przestrzeń

1 Zob. E. Rybicka, Geopoetyka. Przestrzeń i miejsce we wspótczesnych teoriach i praktykach literackich, Kraków 2014. 
w ogóle ${ }^{2}$. Według badaczki można mówić o koncepcyjnym skoku w rozumieniu przestrzeni, miejsca, terytorium i lokalizacji. Pojęcia te są jednocześnie przedmiotem badań, ale też językiem opisu, kategoriami operacyjnymi i narzędziami naukowymi. Inne wymienione przez Rybicką kategorie przestrzenne, które pozwalają na interpretację zjawisk kulturowych, społecznych, historycznych i politycznych, to: „centrum - peryferie, przestrzenie prywatne - przestrzenie publiczne, granica i pogranicze, przestrzenie lokalne, regionalne, narodowe, transnarodowe, globalne, de- $\mathrm{i}$ reterytorializacja, miejsce i heterotopia, geografia wyobrażona i kartografia" ${ }^{3}$.

Mapa, będąca głównym narzędziem analizy utworu, zazwyczaj służy do skonstruowania planu przestrzeni przedstawionej $\mathrm{w}$ dziele. $Z$ jednej strony pozwala wyjaśnić porządek narracji, a z drugiej wzbogacić konkretne miejsca geograficzne o artystyczne realizacje. W artykule Elżbiety Konończuk Mapa w interdyscyplinarnym dialogu geografii, historii i literatury i pracy Rybickiej możemy odnaleźć przykłady takich praktyk interpretacyjnych ${ }^{4}$. Mają one za przedmiot przede wszystkim prozę. Niniejszy artykuł stanowi próbę wykorzystania mapy jako narzędzia do interpretacji spójnej opowieści wyłaniającej się z wszystkich wierszy Tkaczyszyna-Dyckiego. Niemniej jednak rozpoznanie świata przedstawionego $\mathrm{w}$ utworach poety przy pomocy mapy może być użyteczne $\mathrm{w}$ ich interpretacji. Sporządzony podczas lektury wierszy Tkaczyszyna-Dyckiego plan z naniesionymi toponimami, które pojawiają się w twórczości poety, był punktem wyjścia niniejszych rozważań. Taki plan nie stanowi celu samego w sobie, ponieważ autora Peregrynarza postrzegam jako kartografa. Poeta kreujący przestrzeń $\mathrm{w}$ dziele literackim, podobnie jak kartograf pracujący nad mapą, musi wyznaczyć terytorium, dokonać selekcji przedstawianych obszarów, wybrać skalę przedstawienia, podkreślić znaczenie pewnych punktów, stworzyć legendę. Tkaczyszyn-Dycki wciela się w wytwarzającego mapy kartografa, ale jednocześnie zajmuje wobec tej roli i wytworzonych przedstawień terytorium pozycję krytyczną. Autor poddaje stworzone przez siebie mapy interpretacji, przede wszystkim z perspektywy społecznej i etycznej. Poetę interesuje to, co nie-

2 Tamże, s. 18.

3 Tamże, s. 25.

4 Za przykład mogą służyć: Atlas of the European Novel (1800-1900) Franco Morettiego, Atlas literatury Malcolma Bradbury'ego, mapy z trasami wędrówek postaci z Ulissesa Joyce'a z Wykładów o literaturze Władimira Nabokova czy multimedialny projekt Literackich Map Europy pod przewodnictwem Barbary Piatti i Lorenza Hurniego. Por. E. Konończuk Mapa w interdyscyplinarnym dialogu geografii, historii i literatury, „Teksty Drugie” 2011, nr 5; E. Rybicka, Geopoetyka, s. 142-166; http://www.literaturatlas.eu/?lang=en [dostęp 23.09.2015].

5 E. Rybicka, Geopoetyka, s. 152. 
popularne, kontrowersyjne, marginalne i gorsze. Mapa, rozumiana przez współczesną kartografię jako społecznie i kulturowo uwarunkowana reprezentacja rzeczywistości ${ }^{6}$, jest idealnym narzędziem do interpretacji poezji Tkaczyszyna-Dyckiego. W celu odczytania wątków związanych z gorszością i wykluczeniem, do mojej interpretacji włączam konteksty związane z pograniczem i marginesem, o których pisze Ewa Domańska7 ${ }^{7}$ Nieobca Tkaczyszynowi-Dyckiemu jest również refleksja nad mimetyczną funkcją poezji i języka w ogóle. Wiersze poety, w których dokonuje on interpretacji samego procesu twórczego, dotyczą wspólnego dla literatury i kartografii problemu referencji. Rozważania na poziomie metajęzykowym, a więc wszelka refleksja nad wierszem i językiem, której liczne ślady można znaleźć w jego poezji, staje się w takim przypadku refleksją nad słowem i przestrzenią, nad sposobem zapisu doświadczenia przestrzeni $\mathrm{w}$ formie literackiej mapy.

Poetyka wierszy Tkaczyszyna-Dyckiego już od pierwszych tomów wydawała się być spójna i jednolita, jak gdyby poeta nie potrzebował czasu na dojście do optymalnej dla niego formy wiersza ${ }^{8}$. Jak pisał Piotr Śliwiński: „projekt poetycki Dyckiego narodził się w postaci nieomal od razu dojrzałej i właściwie skończonej"9. Można też wspomnieć o drugiej ważnej cesze poezji Tkaczyszyna-Dyckiego, którą jest płynna granica pomiędzy tekstem i życiem. Różnica pomiędzy wierszem a nie-wierszem, pomiędzy egzystencją a kreacją nie jest przy odbiorze tej poezji oczywista. Wszelkiego rodzaju wypowiedzi pozapoetyckie, takie jak wywiad, esej czy nagranie ze spotkania z czytelnikami, nieznaczące $\mathrm{w}$ klasycznej interpretacji, skupionej na immanentnym sensie wiersza, w przypadku autora Piosenki o zależnościach i uzależnieniach wydają się kluczowe, szczególnie jeżeli chcemy rozpatrywać tę poezję $\mathrm{w}$ kontekście zwrotu topograficznego. Istotne miejsce $\mathrm{w}$ ramach rozważań geopoetyckich zajmuje bowiem refleksja nad związkami życia i twórczości z miejscem. Rybicka w Geopoetyce proponuje auto/bio/geo/grafię jako nazwę dla badań na styku biografii, autobiografii i geografii. Zainspirowany takim podejściem interpretacyjnym proponuję, żeby postrzegać miejsca za-

${ }^{6}$ Proces, w trakcie którego mapa przestała być obiektywną reprezentacją rzeczywistości, a stała się narzędziem władzy referuje Maciej Dajnowski w artykule Kilka uwag o domniemanych związkach map i pejzażu literackiego, „Białostockie Studia Literaturoznawcze” 2012, nr 3.

7 E. Domańska, Epistemologie pograniczy, w: Na pograniczach literatury, red. J. Fazan, K. Zajas, Kraków 2012.

8 A. Skrendo, Tkaczyszyn-Dycki i Różewicz. Zarys porównania, w: Pokarmy. Szkice o twórczości Eugeniusza Tkaczyszyna-Dyckiego, red. P. Śliwiński, Poznań 2012, s. 20.

9 P. Śliwiński, Świat na brudno. Szkice o poezji i krytyce, Warszawa 2007, s. 246. 
warte w twórczości laureata Nike z 2009 roku ${ }^{10}$ w łączności z faktami z życia autora. Nie będzie to auto/bio/geo/grafia w sensie ścisłym, ale próba interpretacji w kontekście niektórych wydarzeń z życia poety. Oznacza to zgodę na lekturę łączącą wiersze z wypowiedziami niepoetyckimi (eseje, wywiady, biografia) i z miejscami geograficznymi. Do takiego sposobu lektury zachęca Małgorzata Czermińska w artykule Miejsca autobiograficzne. Propozycja w ramach geopoetyki, gdzie przekonuje, że przyjęcie hipotezy „zbiorowego, syntetycznego podmiotu dzieł wszystkich jednego autora" jest ontologicznie uzasadnione, a jej stosowanie sprzyja lepszemu rozumieniu literatury ${ }^{11}$. Według badaczki miejsce autobiograficzne jest:

znaczeniowym, symbolicznym odpowiednikiem autentycznego miejsca geograficznego oraz związanych $z$ nim kulturowych wyobrażeń. Nie istnieje $w$ geograficznej próżni, nie odnosi do przestrzeni geometrycznej, uniwersalnej i pustej. Związane jest zawsze $\mathrm{z}$ topograficznym, uniwersalnym konkretem, nawet jeśli zostaje on poddany przekształceniom literackim, właściwym nie tylko metaforze, możliwej w konwencji realistycznej, ale także prawom oniryzmu i fantastyki ${ }^{12}$.

Interpretacja twórczości Tkaczyszyna-Dyckiego, odwołująca się do kategorii miejsca autobiograficznego, wydaje się być w tym wypadku uzasadniona. Poezja i „życie” w wierszach tego poety są ze sobą bardzo silnie zespolone na różnych poziomach, także na poziomie przestrzeni przedstawionej. Przekształcenie konkretu topograficznego w jego literacką reprezentację w przypadku Tkaczyszyna-Dyckiego mieści się w konwencji realistycznej. Konkretność miejsca nie zostaje zatarta $\mathrm{w}$ wyniku zastosowania poetyki oniryzmu czy fantastyki, lecz celowo wyeksponowana dzięki nazwom miejscowym, i nazwiskom. Zwracam również uwagę, że związki pomiędzy realnym miejscem geograficznym, jego poetyckim, wytworzonym przez Tkaczyszyna-Dyckiego odpowiednikiem i kulturowymi wyobrażeniami dotyczą również problemu mapy i terytorium. Celem artykułu jest próba odczytania, za pomocą narzędzia mapy, doświadczenia przestrzeni zapisanego w poezji autora Kochanki Norwida.

10 Za tom Piosenka o zależnościach i uzależnieniach.

11 M. Czermińska, Miejsca autobiograficzne. Propozycja w ramach geopoetyki, „Teksty Drugie” 2011, nr 5, s. 183.

12 Tamże, s. 188. 


\section{Podmiot dzieł wszystkich}

Igor Piotrowski w artykule Słowo, obraz, terytorium. W stronę kulturowej analizy map pisze o specyfice mapy z perspektywy semiotyki. Mapa jest bowiem przedmiotem składającym się z trzech elementów: słowa (znak językowy), obrazu (znak ikoniczny) i terytorium (desygnat). Co więcej, mapa potrzebuje obecności każdego z nich, by została odczytana. Brak któregoś z elementów sprawia, że schemat staje się wyłącznie obrazem czy tekstem ${ }^{13}$. „Mapa pozbawiona tekstu jest częstokroć w ogóle nieczytelna. Podobnie ma się rzecz z terytorium, czyli desygnatem mapy"14 - zwraca uwagę Piotrowski. Badacz zwraca uwagę na tekstowy wymiar mapy, który tworzy przede wszystkim grupa nazw własnych. Poezja opisująca konkretne terytorium również zawiera w sobie wiele nazw miejscowych. Jednym z powodów, dla których zwracam uwagę na mapę w twórczości Tkaczyszyna-Dyckiego, jest liczna grupa nazw własnych obecnych w jego wierszach. Poeta nie ogranicza się jedynie do stworzenia mapy terenu $\mathrm{z}$ naniesionymi nazwami miejscowymi. Tworzony schemat zostaje bowiem wzbogacony o antroponimy. Co więcej, Tkaczyszyn-Dycki, interpretując powstałą w ten sposób mapę, nakłada na nią kolejne warstwy, porównuje i kompiluje. Poeta zestawia ze sobą na przykład obecną mapę, na której nie ma województwa przemyskiego, i historyczną, która wytycza dawne granice województw. Innym działaniem jest tworzenie mapy językowej, którą interpretować należy biorąc pod uwagę bolesne wspomnienia związane z matką autora i społecznym wykluczeniem doświadczonym przez poetę z powodu jego ukraińskich korzeni. Przykładem przynajmniej trzech różnych map może być cykl otwierający przedostatni tom Tkaczyszyna-Dyckiego zatytułowany Gniazdo ${ }^{15}$. Autor wymienia tu z nazwiska bardzo wielu ludzi zamieszkujących teren gminy Lubaczów. Są to dobrze znani czytelnikowi jego poezji Ilniccy czy Hryniawscy, obok rzadziej wymienianych Dzięgielewskich, Oziębłowskich czy Kulczyckich. Cykl wierszy Gniazdo wydaje się interesujący z powodu przypisu, który poeta umieścił na końcu książki. Jest to cenne dopowiedzenie nie tylko w świetle biograficznych wątków z tomiku Imię i znamię, ale w ogóle całej

13 I. Piotrowski, Stowo, obraz, terytorium. W stronę kulturowej analizy map, w: Stowo/obraz, red.

G. Godlewski, Warszawa 2010, s. 130.

14 Tamże.

15 Zob. Eugeniusz Tkaczyszyn-Dycki, Imię i znamię, Wrocław 2012, s. 5-11. Kolejne cytaty $\mathrm{z}$ tego tomu oznaczać będę $\mathrm{w}$ tekście skrótem IZ. Tom Oddam wiersze w dobre ręce, Wrocław 2010 oznaczam skrótem OW, tom Kochanka Norwida, Wrocław 2014 oznaczam skrótem KN. Wszystkie kolejne cytaty za tymi wydaniami. 
twórczości Tkaczyszyna-Dyckiego. Jak zaznacza sam autor, jest to przypis "między innymi" do wierszy z cyklu Gniazdo. Cytuję w całości:

W Ukraińskiej Powstańczej Armii (UPA) znaleźli się wszyscy członkowie mojej rodziny po kądzieli (nie tylko dziadek i jego trzej bracia), jednakże ich przynależność do ukraińskiego podziemia była przede mną ściśle ukrywana do mniej więcej 15 roku życia. W domu mojego spolonizowanego ojca był to temat tabu. Podobnie jak przeszłość matki, deportowanej z Lubaczowszczyzny w 1947 roku wraz z całą unicką (grekokatolicką) rodziną. Dzięki małżeństwu moja matka mogła wrócić w Lubaczowskie (jako banderówka, córka rezuna), zmieniając wyznanie i przyjmując katolicyzm w Wydminach koło Giżycka. W tamtejszym kościele parafialnym.

Dodam przy okazji, nieco chaotycznie, że babcia i matka były deportowane i zmuszone do osiedlenia się we wsi Boćwinka koło Kruklanek (okolice Giżycka), natomiast krewni Jakimowiczowie i Kwilińscy osiedli we wsi Wojciechy (okolice Bartoszyc), tym bowiem skończyła się dla nas akcja „Wisła” w 1947 roku. Rozproszeniem, zniszczeniem i wynarodowieniem.

I jeszcze jedno. Wyjątkowych trudności przysparzał fakt, że mój ojciec, ulegając polonizacji, stał się agresywnym polskim nacjonalistą, choć nadal posługiwał się tzw. językiem chachłackim, mieszaniną polskiego i ukraińskiego, który zresztą był moim pierwszym językiem (mżenia, czyli garść; kubania, czyli kałuża; kiła kiczka, czyli jaśmin; kuteń, czyli żołądek), zarzuconym około 1977 roku po opuszczeniu Wólki Krowickiej i zamieszkaniu w Lubaczowie [IZ, s. 56].

Przypis wydaje się interesujący z paru względów. Przede wszystkim można go czytać jako mapę składającą się z trzech poziomów. Po pierwsze, zawarte zostały tu nazwy miejscowe (Lubaczowszczyzna, Wydminy koło Giżycka, wieś Boćwinka koło Kruklanek, Wojciechy, Bartoszyce, Wólka Krowicka), rozrysowany został schemat przestrzeni, którą zamieszkiwał, w której bywał albo o której czytał poeta. Po drugie, na podstawową mapę z wymienionymi toponimami naniesiono nazwy osobowe (Jakimowicze, Kwilińscy). Po trzecie, można tu mówić o elemencie geografii lingwistycznej, oczywiście nacechowanej ściśle indywidualnym doświadczeniem. Tak rozrysowana, składająca się z trzech elementów mapa, spełnia dwie funkcje. Pierwsza polega na ulokowaniu poezji Tkaczyszyna-Dyckiego w konkretnej przestrzeni, co jednocześnie sprawia, że konkretna przestrzeń staje się podstawą utworu. Druga funkcja mapy to krytyczna refleksja, która służy namysłowi nad etycznymi i społecznymi konsekwencjami zamieszkiwania człowieka w przestrzeni. Będą to wątki związane $\mathrm{z}$ historią pogranicza polsko-ukraińskiego, granicami województw, wykluczeniem społecznym i wszelkimi przejawami opresji, czy to ze strony władzy rozumianej jako administracja państwowa, czy opresji wynikającej z czynników kulturowych (np. stereotypów). O ile pierwsza funkcja ma rolę obiektywnego zakotwiczenia w przestrzeni (choć 
sam akt wyboru jest subiektywny), o tyle druga ma charakter ściśle indywidualny, wynikający z biografii. Taka mapa jest rysowana z perspektywy poety-kartografa, który pyta o konsekwencje określanych przez władzę granic i ograniczeń. Niezależnie od tego czy władzę sprawuje państwo, społeczeństwo czy autorytet. Poezja Tkaczyszyna-Dyckiego stanowi również przykład praktyki artystycznej, w ramach której poeta nadaje przestrzeni swoje własne sensy. Akt literacki jawi się tu jako poszukiwanie swojego miejsca w przestrzeni/świecie/literaturze, przy jednoczesnym zaprzeczaniu i dekonstruowaniu wytworzonych sensów. Świadczy o tym refleksja metajęzykowa i metaliteracka.

Przypis stanowi również rodzaj „paktu autobiograficznego" zawartego z czytelnikiem. Tkaczyszyn-Dycki zaświadcza o swojej przeszłości, historii rodziny i intymnych szczegółach ze swojego życia. Robi to w sposób otwarty i klarowny. Przypis kwalifikuje się jako inny rodzaj tekstu niż ulotne wypowiedzi na spotkaniach autorskich, strzępy informacji zawartych $\mathrm{w}$ biogramie czy powtarzane przez czytelników przypuszczenia lub plotki. Zamieszczenie tego rodzaju informacji $\mathrm{w}$ tomiku poetyckim jest zabiegiem intencjonalnym i nie pozostaje bez wpływu na sposób interpretacji wierszy autora Piosenki o zależnościach i uzależnieniach. Stanowi zachętę do czytania jego poezji na wskroś biograficznie. Twórczość Tkaczyszyna-Dyckiego czytana w kontekście mapy stanowi językową część tego semioforu ${ }^{16}$, do którego istnienia niezbędne jest słowo, obraz i terytorium. To poezja, która podobnie jak mapa, służy refleksji nad rzeczywistością i jej językową reprezentacją.

Istotny w przypisie do wierszy z cyklu Gniazdo jest styl wypowiedzi. Kolejne informacje pojawiają się na zasadzie skojarzeń. W efekcie tekst przypomina wiersze Tkaczyszyna-Dyckiego, w których konkretne miejsca i konkretni bohaterowie są przyczynkiem do lawiny dopowiedzeń, powtórzeń, plotek i nieistotnych informacji. Wydaje się, że poeta nigdy nie jest usatysfakcjonowany swoją wypowiedzią, która zawsze potrzebuje uzupełnień. Przypis nosi cechy literackie zbieżne z poezją Tkaczyszyna-Dyckiego ze względu na liczbę przytoczonych faktów. Niektóre z nich odnoszą się do tomiku Imię $i$ znamię i uzupełniają informacje o świeżo wprowadzonych do twórczości postaciach, na przykład o ojcu nacjonaliście. Przypis jest istotny w perspektywie całej twórczości, bo opowiada o historii matki, osobie bardzo ważnej

16 Por. K. Pomian Historia. Nauka wobec pamięci, Lublin 2006, s. 100-102, 115-139. Piotrowski używa pojęcia Krzysztofa Pomiana, który semioforem nazywa „przedmioty widzialne wyposażone w znaczenia": Tamże, s. 121. 
dla poezji Tkaczyszyna-Dyckiego. Jednak większość z zawartych w przypisie treści nie służy wyjaśnieniu wcześniej poruszonych wątków. Poeta, niczym w niepublikowanym dotąd wierszu, wprowadza nowych bohaterów, takich jak Jakimowicze czy Kwilińscy, wzbogaca mapę istotnych miejsc o Boćwińki czy Kruklanki, zawiera w przypisie również parę dat. Autor, zdecydowawszy się na sporządzenie przypisu, objaśnienie pewnych wątków, nie może się powstrzymać przed dygresyjnością. Doskonale widać to $\mathrm{w}$ formach wprowadzających typu: „Dodam przy okazji”, „I jeszcze jedno”. Proces ciągłego dopowiadania przypomina rysowanie mapy, której terytorium nie ma końca i wciąż rozrasta się wzbogacane o szczegóły, a sporządzający ją kartograf potrzebuje coraz mniejszej skali, by oddać każdy detal.

\section{Wólka Krowicka, czyli zakotwiczenie poezji}

Mapa Tkaczyszyna-Dyckiego posiada centrum, którym jest Wólka Krowicka. Miejscowość należy do gminy Lubaczów, znajdującej się we wschodniej części powiatu lubaczowskiego położonego na terenie województwa podkarpackiego. W długiej historii tej gminy (pierwsze osady wokół Lubaczowa zaczęły powstawać około IX-X wieku) wielokrotnie przesuwano linie podziału administracyjnego. Po odzyskaniu przez Polskę niepodległości Lubaczów pełnił funkcję miasta powiatowego, które wchodziło w skład województwa lwowskiego. Zmiany przyniosła II wojna światowa, podczas której powiat przestał istnieć. $W$ tym miejscu przebiegała granica pomiędzy Związkiem Radzieckim i Niemcami. Po wojnie powiat odradza się i zostaje włączony do województwa rzeszowskiego. W 1975 r. Lubaczów ponownie traci rangę ośrodka powiatu i staje się częścią województwa przemyskiego. Reforma samorządowa w 1999 r. zmienia granice administracyjne i gmina Lubaczów staje się częścią województwa podkarpackiego ${ }^{17}$.

W poezji Tkaczyszyna-Dyckiego Lubaczów pojawia się, gdy bohater odwiedza mieszczący się tam cmentarz. Najczęściej wymienianą nazwą miejscową jest z kolei Wólka Krowicka. Dosyć często autor wymienia też Krowicę Hołodowską, Borową Górę, Lisie Jamy, Wielkie Oczy. Są to wsie znajdujące się w jednej okolicy. Spośród większych miast, które są istotnymi punktami na literackiej mapie Tkaczyszyna-Dyckiego, na pierwszym miejscu należy wymienić Lublin, gdzie poeta studiował filologię polską. Kilkukrotnie pojawiają się również Warszawa i Przemyśl.

17 G. Szafran, J. Mazur, Środowisko przyrodnicze i kulturowe Gminy Lubaczów. Przewodnik ekoturystyczny, Lubaczów 2008, s. 61-63. 
Językowa warstwa mapy, którą tworzy poezja Tkaczyszyna-Dyckiego, ma charakter procesualny. Oznacza to, że ważne dla poety miejsca nie pojawiają się jednorazowo, a nieustannie powracają i zostają dokładniej opisane. Poeta czyni to na różne sposoby. Niektórym miejscom poświęca poszczególne tomiki, w których powtarzany toponim staje się powracającym co kilka stron refrenem (dotyczy to szczególnie ostatnich dwóch Imię i znamię i Kochanka Norwida). Inne nazwy wracają jako temat na zasadzie spirali (Wólka Krowicka), a część z nich pojawia się jedynie epizodycznie. Żaden z tych wariantów nie jest ostateczny, bo dopóki powstają kolejne wiersze, dopóty mapa Tkaczyszyna-Dyckiego utrzymuje swój procesualny charakter i rozwija się w czasie. Część z opisywanych przestrzeni może zostać zidentyfikowana $\mathrm{w}$ kolejnych tomikach, choć wiele $\mathrm{z}$ nich dalej pozostaje anonimowych. W zależności od zbioru wierszy toponimy w twórczości autora Piosenki o zależnościach i uzależnieniach występują w bardzo różnej liczbie. O ile w większości tomików liczba nazw miejscowych nie przekracza dziesięciu (poza wyjątkowym Przyczynkiem do nauki o nieistnieniu, w którym występuje ich około dwudziestu), o tyle w każdym z dwóch ostatnich zbiorów (Imię $i$ znamię i Kochanka Norwida) znajduje się blisko trzydzieści różnych toponimów. Przestrzeń przedstawiona $\mathrm{w}$ wierszach Tkaczyszyna-Dyckiego w ostatnich tomikach zyskała konkretną lokalizację, co idzie w parze z przybierającym na sile autobiografizmem tych utworów. Poeta nie rezygnuje z zabawy językiem i uwag metapoetyckich, które zawsze stanowiły ważny temat tej twórczości, dzieje się to jednak w coraz bardziej konkretnej przestrzeni wschodniej Polski. Z perspektywy geopoetyki można powiedzieć, że dopiero na obecnym etapie odczytujemy z twórczości Tkaczyszyna-Dyckiego nazwy własne nanoszone na rozrysowane wcześniej przestrzenie. Poezja ta coraz silniej zakotwicza się w konkretnej przestrzeni geograficznej.

Gdyby wskazać fragment mapy Polski, który szczególnie interesuje autora tomu Imie $i$ znamię, byłyby to tereny południowo-wschodnie. Wymienione z nazwy miejsca odnoszą się przede wszystkim do województwa podkarpackiego i gminy Lubaczów, a więc przestrzeni, w której wychował się poeta. Jak zostało pokazane, są to miejsca, które łatwo mogą zostać zidentyfikowane. Przywoływany przez znak językowy (który też staje się tematem poezji) realny konkret przestrzeni geograficznej stanowi istotny do odczytania tej poezji kontekst. Pamięć zbiorowa tych miejsc spleciona jest nierozerwalnie z pamięcią indywidualną autora. Odpowiednim komentarzem wydają się słowa Rybickiej dotyczące Dukli Stasiuka:

Nazwa stanowi więc szczelinę wiodącą do złóż pamięci, ujście w głąb pamięci prywatnej, a zarazem, już w kontekście całego opowiadania, pamięci kulturowej 
miejsca. Niemniej obok tej semantyki mnemicznej, co podkreślam, ważna jest jej funkcja indeksalna, związek z jak najbardziej realną geografią i historią miejsca na mapie Polski ${ }^{18}$.

Badaczka w swoim wywodzie powołuje się na Rolanda Barthesa, który pisał o toponimiach u Prousta, spełniających nie tylko funkcję znaku i wskaźnika, ale również wieloznacznej figury poetyckiej. Ostatecznie Rybicka stwierdza, że „toponimie oscylują tu pomiędzy dwoma biegunami geopoetyki - między geografią a poiesis, między zahaczaniem w lokalności i owej lokalności wywoływaniem"19. Podobnie rzecz ma się u Tkaczyszyna-Dyckiego, który używając nazw własnych, wskazuje na krainę geograficzną i przywołuje kontekst miejsca. Nazwa (poeta napisałby „imię”) jednocześnie spełnia funkcję poetycką, służy metaforze, odnosi się do porządku języka i literatury.

Sztuka tworzona przez autorów pochodzących z terenów uznawanych za peryferyjne różni się od sztuki, tworzonej przez autorów wychowanych w kulturalnych i cywilizacyjnych centrach. Powstające $w$ przestrzeni peryferyjnej dzieła zyskały zainteresowanie badaczy, co pozwoliło na wytworzenie nowej metafory epistemologicznej pogranicza. Jedną z wyróżniających pogranicza (marginesy, peryferia) cech jest specyfika tej przestrzeni jako strefy spotkań różnych grup interesów. Pozwala to na kontestację głównego nurtu kultury i decentralizację władzy ${ }^{20}$. Proces dowartościowywania pogranicza doskonale widać na przykładzie intrygującej liryki Tkaczyszyna-Dyckiego. O roli, jaką Wólka Krowicka odgrywa w jego życiu i twórczości, poeta wypowiedział się w tomach Imię $i$ znamię i Kochanka Norwida. Istotnym i często poruszanym problemem twórczości Tkaczyszyna-Dyckiego jest autobiografizm tej poezji. Do odczytań utożsamiających autora z bohaterem wierszy skłaniają komentarze samego poety, ale również silnie podmiotowy i tożsamościowy wymiar tej poezji. Jednocześnie poeta zdaje się niejednokrotnie chować za murem zbudowanym z języka poezji, posługując się, na przykład w rozmowach, fragmentami swoich "piosenek”, co osłabia interpretacje tworzone w oparciu o biografię. Agnieszka Czyżak rozwiązuje ten paradoks przez przeniesienie ciężaru wyboru pomiędzy fikcją a życiem na odbiorcę:

Odbiór tej poezji zależy zatem od stopnia zawierzenia intencji twórcy - stąd rozpięty bywa pomiędzy biegunowo różnymi odczytaniami, z jednej strony jako stylizatorskiej gry konwencjami, z drugiej natomiast jako ekshibicjonistycznego drążenia tajników samo(nie)świadomości. Badacze jednak, niezależnie od

18 E. Rybicka, Geopoetyka, s. 320.

19 Tamże.

20 E. Domańska, Epistemologie pograniczy, s. 94. 
oceny efektów, od początku wskazywali, iż sednem poetyckich poszukiwań Dyckiego jest konsekwentne dociekanie istoty zagadnienia tożsamości, badanie jej trudnych do pochwycenia granic, wkrótce ewoluujące ku równie świadomemu tekstowemu kreowaniu i dookreślaniu tejże wielokrotnie rozszczepionej tożsamości ${ }^{21}$.

Poeta/bohater zręcznie wymyka się próbom tradycyjnego krytycznoliterackiego opisu. Czyżak nie określa, czy w sporze o sposób lektury poezji Tkaczyszyna-Dyckiego opowiada się po stronie badaczy przekonanych o autokreacji poety czy zwolenników odczytań egzystencjalnych, zamiast tego wskazuje na indywidualne "zawierzenie intencji twórcy" jako wyznacznik $\mathrm{w}$ sposobie odbioru poezji autora Liber mortuorum. Badaczka spogląda na problem $\mathrm{z}$ innego punktu widzenia, wskazując na zagadnienie rozszczepionej, ewoluującej tożsamości jako naczelny temat poezji Tkaczyszyna-Dyckiego. W ten sposób Czyżak ukazuje fikcję i doświadczenie jako dwie strony tej samej monety. Innym rozwiązaniem problemu kreacji i egzystencji jest spojrzenie z perspektywy geopoetyki. Miejsce pozwala spoić w jednym punkcie geograficznym rozsypane dotąd fragmenty tożsamości, choć mapa, którą posługuję się $\mathrm{w}$ niniejszej interpretacji, o problemach $\mathrm{w}$ reprezentacji przestrzeni nieustannie przypomina.

Poeta ujawnia swoją podmiotowość wtedy, gdy sam siebie strofuje: „to ty jesteś pożałowania / godny głuptas trzeba czy nie trzeba Dyciu / dekonspirujesz się w każdym wierszu" [s. 350]. Także konkretne przestrzenie, ich historia i lokalizacja, opowiadane są z perspektywy piszącego autora/bohatera. Tkaczyszyn-Dycki, niczym w XIX-wiecznej powieści realistycznej, wskazuje na miejsce urodzenia, od którego zaczyna się opowiadana przez niego historia. Upowieściowienie realizuje się, między innymi, dzięki tradycyjnemu zwrotowi „do życzliwego czytelnika”:

oto mój Peregrynarz poszedł w twoje pewne ręce abyś się wypowiedział możesz zakwestionować talent i wykrzyknąć śmielej przecież urodziłeś się w Wólce Krowickiej

[LXXIX. Ad benevolum lectorem, OW, s. 99]

Wiejskie pochodzenie, peryferyjne umiejscowienie domu mogą, według bohatera wierszy, stanowić przedmiot drwin, służyć mechanizmom wykluczenia. Czy to na poziomie wspólnoty - szkoły, wsi, miasta, czy na poziomie dyskursu - politycznego, społecznego, kulturowego, literackiego. W takiej

21 A. Czyżak, Wnuk rezuna, w: Pokarmy, s. 266. 
narracji marginesy to miejsca represji i deprecjacji. W Biblii znajduje się fragment, w którym Jezus odwiedza Nazaret, swoją ojczyznę. Jest to początek jego ewangelicznej działalności, która zaczyna się po powrocie Chrystusa z pustyni. Po przeczytaniu fragmentu z księgi Izajasza Nazarejczyk zaczyna przemawiać do obecnych w świątyni. Żydzi są zdziwieni talentem mówczym Jezusa: „A wszyscy przyświadczali Mu i dziwili się pełnym wdzięku słowom, które płynęły z ust Jego. I mówili: "Czy nie jest to syn Józefa»" [Łk 4, 22]. Chrystus uprzedza pretensje słuchaczy, których bulwersuje brak cudów w rodzinnym mieście. Mówi: „Zaprawdę, powiadam wam: żaden prorok nie jest mile widziany w swojej ojczyźnie" [Łk 4, 24]. Fragment kończy się próbą nieudanego zamachu na Jezusa. Słuchaczy wzburzyły zapewne fragmenty ze Starego Testamentu, które opowiadają o łasce Boga skierowanej do pogan i obcych, a nie do pobożnych Izraelitów. Chrystus prowokuje swoich krewnych i sąsiadów. Z kolei Tkaczyszyn-Dycki pisze: „możesz mnie poszturchując nazywać durnym / a biada nam kiedy durny chwyta się polszczyzny / jak dziewki bo z tego żadnych wierszy nie będzie". Ponownie słychać tu echo czytanej wnikliwie przez Tkaczyszyna-Dyckiego w dzieciństwie Biblii i wypowiedzianych przez Natanaela do Filipa słów: „Czyż może być co dobrego z Nazaretu?" (J 1, 46). Autor swoją poezją prowokuje niemal nieustannie. Czy to na spotkaniach z czytelnikami, ze względu na charakterystyczny sposób recytacji, czy to $\mathrm{w}$ samych tekstach, dotykając tematów niewygodnych i niepopularnych, opowiadanych w sposób dziwny, groteskowy i zaskakujący czytelnika ${ }^{22}$. Poeta mówi o sobie jako o niechcianym i gorszym:

Miałem zawsze problem z gorszością, mówiłem sobie, że jestem Polaczysko, ale ten gorszy, ponieważ mój język polski, bez wątpienia ten gorszy język polski, pojawił się w mojej polszczyźnie mniej więcej w 1978 roku. Pamiętam to jak dziś, bo moja babcia zdecydowała, że pójdę do polskiej szkoły, a w polskiej szkole dostałem wpierdol od polskich chłopaków, dlatego, że nie umiałem jak polskie dzieciaki reagować na tę samą rzeczywistość.

[...]

Wiele razy mówiono mi, że jestem ten gorszy i przyjąłem do wiadomości, że jestem ten gorszy, ale jednocześnie powiedziałem sobie: że kurwa ja wam pokażę, ja wam jeszcze pokażę, że nie jestem taki najgorszy. Poeta powinien powiedzieć, pisarz polski powinien powiedzieć, że będzie pomagał tym, którzy są flekowani albo pozostawieni samym sobie ${ }^{23}$.

22 Zob. B. Przymuszała, Tkaczyszyn-Dycki - projekt aprowokacji, w: Pokarmy, s. 9-16.

23 E. Tkaczyszyn-Dycki, Piosenka o zależnościach i uzależnieniach. Zapis rozmowy z Eugeniuszem Tkaczyszynem-Dyckim przed Gala Literackiej Nagrody Nike 2009, towarzyszący premierze ksią̇ki Oddam wiersze w dobre ręce (1988-2010), http://portliteracki.pl/przystan/teksty/piosenka-o-zalez nosciach-i-uzaleznieniach-2/ [dostęp 05.05.2015]. 
Ślady tej wypowiedzi odnajdujemy w cytowanym już wierszu, który kończy się wersami: „możesz zakwestionować talent i wykrzyknąć śmielej / coś skory wykrzyknąć lecz ja się nie cofnę o nie". Adresat tej wypowiedzi mógłby wykrzyknąć: "Czy to nie Dycki, syn Stefanii z Wólki Krowickiej?”. Status „wariatki”, który miała we wsi matka poety, nie pomagał synowi w uzyskaniu akceptacji lokalnej społeczności. Gorszość, w którą wyposażony został autor, daje siłę do mówienia o sobie samym, zachęca do pracy. Wiersz Ad benevolum lectorem wydaje się być wymierzony przeciw tym, którzy wykluczyli go i zmarginalizowali. Tkaczyszyn-Dycki w swej twórczości, na wzór biblijnego proroka, powraca do ojczyzny. Wiersze wypełniają kolejne postaci z przeszłości, krewni, kuzyni, sąsiedzi, a więc ci, którzy naznaczyli go piętnem Wólki Krowickiej. Nie są oni jednak przedstawieni jednostronnie. Zauważa to Agnieszka Czyżak, pisząc o cyklu wierszy Gniazdo:

Wszyscy oni jednak tym razem ukazani zostali z dwóch perspektyw jednocześnie: z perspektywy próbującego odnaleźć swą przynależność do wiejskiej wspólnoty pastuszka i człowieka dojrzałego, który pamięta akty piętnowania znamieniem obcości potomków rezuna ${ }^{24}$.

W poezji Tkaczyszyna-Dyckiego następuje zatem powrót do miejsca, które go ukształtowało, ale jednocześnie napiętnowało. Przeszłość w Wólce Krowickiej uczyniła go poetą, ale też wypaczyła i zraniła, w odwecie za co należy się z tą przeszłością cały czas rozliczać. Tkaczyszyn-Dycki, niczym prorok, powraca do swojego Nazaretu i przemawia, prowokuje, wyśmiewa. Robi to, bo nie może odłączyć się od dzieciństwa w gminie Lubaczów. Jak sam wspomina:

W pewnym momencie zorientowałem się, że dom organizuje mnie emocjonalnie po stronie tego wszystkiego, co się w nim rozgrywa, że opłakujemy kolejnych Dyciów, a więc Tkaczyszynów-Dyckich, Hryniawskich, Bernackich, czekają zaś wymierający Ilniccy, Bojarscy, Bukiccy i wyobraziłem sobie, że od tego nie ma ani odbicia, ani jakiejkolwiek bądź ucieczki. Godziłem się z tą sytuacją do czasu, gdy poszedłem na studia i wnet zorientowałem się, że mogę zupełnie inaczej ułożyć i uporządkować swoje życie, oddalić - z dnia na dzień - to wszystko, co mi było dotąd fundowane. I zrobiłem to niemal natychmiast, po głupiemu, durnowato, nie umiejąc zaproponować ani sobie, ani rodzinie łagodnego przejścia. Po paru latach, na szczęście, przyszło opamiętanie, że istotnie nie ma ucieczki od tego, co zostawiam bądź już zostawiłem, że tak naprawdę

24 A. Czyżak, Wnuk rezuna, s. 267. 
opłakiwanych Dyciów nie można gdzieś tam pogrzebać i zaniechać, że to jest w jakiś sposób we mnie, że jeśli nie ubogaca, to uwrażliwia na sytuację, której muszę podołać ${ }^{25}$.

Paradoksalnie to poczucie gorszości, które niemal dosłownie wbito Tkaczyszynowi-Dyckiemu do głowy, pozwoliło mu stać się poetą, dało szansę na zajmowanie się tymi, którzy są "flekowani". Silnie podmiotowy charakter jego twórczości, o którym często wspomina się w opracowaniach, ulega $\mathrm{w}$ tym rozumieniu rozproszeniu. Poezja Tkaczyszyna-Dyckiego posługuje się figurą Innego - gorszego, słabszego, wykluczonego. Poetyckie wersje powyższych wypowiedzi odnajdujemy we fragmencie wiersza CLXXXII.:

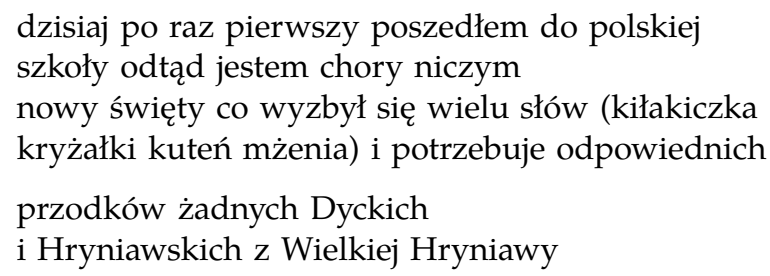

[OW, s. 213]

Fragment ten dobrze ilustruje, w jaki sposób inność manifestuje się przez język. Bohater, który w tym momencie pragnie porzucić swój słownik, musi równocześnie porzucić też swoich dotychczasowych patronów. Język rozpatrywany jest ze swojej historycznej perspektywy, w której wyrasta z pewnego dziedzictwa przodków. Jednocześnie istotna jest pragmatyczna strona wypowiedzi, gdyż Tkaczyszyn-Dycki, parafrazując lub cytując różne osoby, niejednokrotnie przedstawia bohaterów wierszy w ich językowej aktywności. Jeszcze jeden element zwraca uwagę z perspektywy mapy. Przykłady leksykalne (kiłakiczka, kryżałki, kuteń, mżenia) mają swoją lokalizację, którą jest pogranicze polsko-ukraińskie, doprecyzowane przez przywołanie Hryniawskich z Wielkiej Hryniawy.

Poezja Tkaczyszyna-Dyckiego jest silnie lokalna, to znaczy umiejscowiona $\mathrm{w}$ konkretnej przestrzeni, co najdobitniej potwierdził Przypis m.in. do cyklu siedmiu wierszy pod tytułem "Gniazdo". Cykl wierszy pokazuje, jak ważne dla poety jest kreowanie przestrzeni odsyłającej czytelnika do konkretnego terytorium. Utwory poetyckie Tkaczyszyna-Dyckiego, w kontekście rozróżnienia poczynionego przez Piotrowskiego, stanowią językowy element

25 E. Tkaczyszyn-Dycki, Pójście za Norwidem. Wypowiedzi Eugeniusza Tkaczyszyna-Dyckiego. Za stowa tapie Anna Podczaszy, http://portliteracki.pl/przystan/teksty/pojscie-za-norwidem/ [dostęp 05.05.2015]. 
mapy, która nie może obejść się bez desygnatu przestrzeni. Opisy tematyzujące komplikacje językowe zachodzące $\mathrm{w}$ trakcie procesu przedstawiania są również składnikiem tej twórczości. Przypis, jak i kolejne wiersze pokazują, że językowa mapa, którą tworzy Tkaczyszyn-Dycki, rozbija się na trzy przenikające się, przemieszane warstwy: toponimów, antroponimów i języków. Pojedyncze wiersze zazwyczaj stanowią mapy w dużej skali, zbliżenia wykonane w określonym miejscu, w którym autor przygląda się konkretnej miejscowości, nazwie, nazwisku bądź samej czynności tworzenia poezji/mapy.

\section{Literary Map of Eugeniusz Tkaczyszyn-Dycki}

\section{Summary}

This article utilizes a map as an interpretative tool for Eugeniusz Tkaczyszyn-Dycki poetry. His works are interpreted through his biography and through geographic locations in Lubaczów region. His poetry further becomes a register of the space experienced by the poet.

Keywords: map, geographic space, autobiographic place, borderland, Eugeniusz Tkaczyszyn-Dycki 